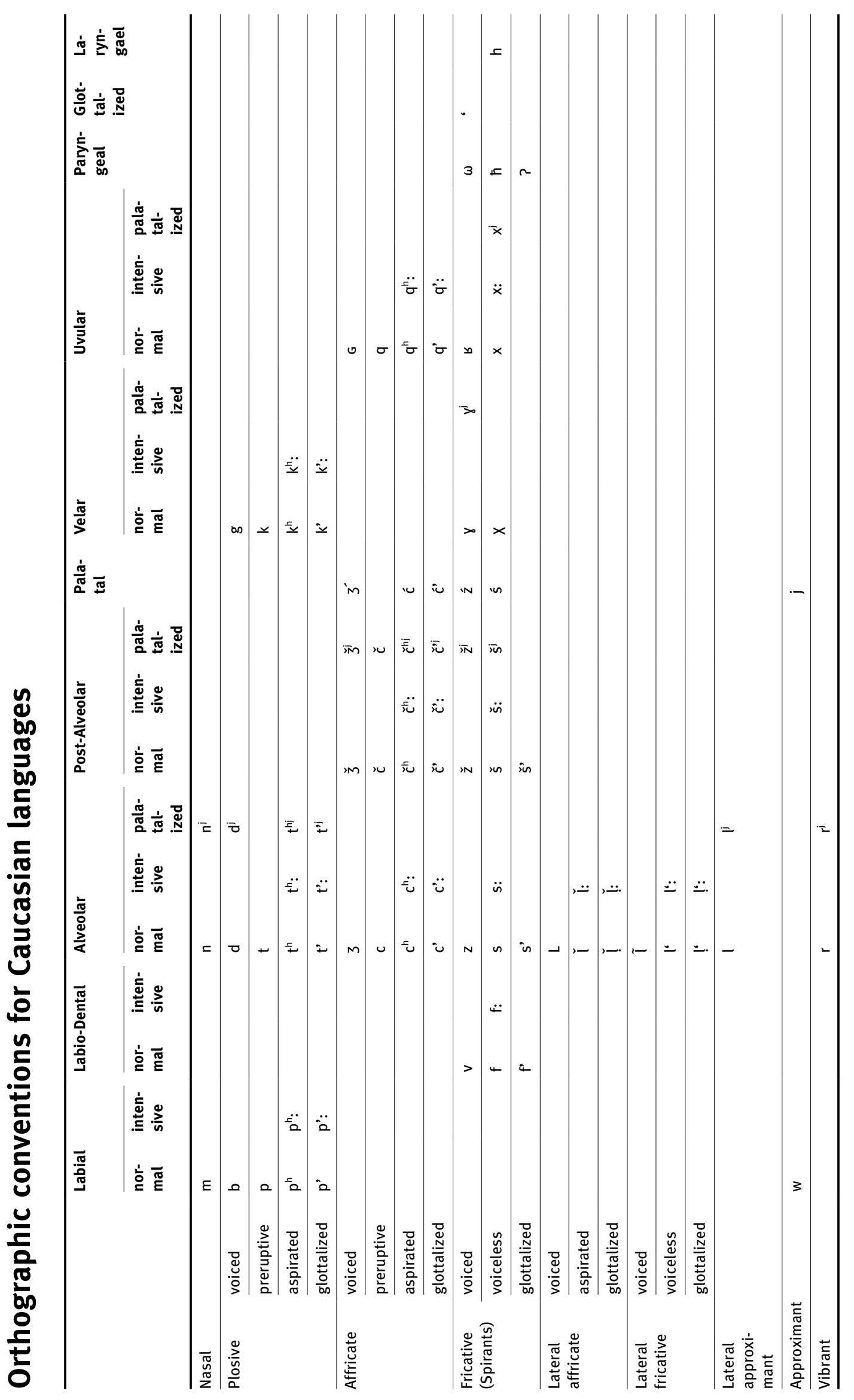




\begin{tabular}{|c|c|c|c|c|c|c|c|}
\hline & \multicolumn{2}{|l|}{ Front } & \multicolumn{2}{|l|}{ Central } & \multicolumn{2}{|l|}{ Back } & \multirow[t]{2}{*}{ Suprasegmentals } \\
\hline & Unrounded & Rounded & Unrounded & Rounded & Unrounded & Rounded & \\
\hline \multirow[t]{6}{*}{ close } & $\mathrm{i}$ & $\ddot{u}$ & & & & u & Simple \\
\hline & & ü: & & & & $\mathrm{u}:$ & Long \\
\hline & ì & & & & & $\check{u}$ & Short \\
\hline & ! & & & & & ب̣ & Pharyngeal \\
\hline & $\tilde{\imath}$ & & & & & $\tilde{\mathrm{u}}$ & Nasal \\
\hline & í & & & & & & Stressed \\
\hline \multirow[t]{6}{*}{ mid } & e & ö & ә & & & 0 & Simple \\
\hline & e: & & & & & $0:$ & Long \\
\hline & ĕ & & & & & $\check{o}$ & Short \\
\hline & ẹ & & ә. & & & o & Pharyngeal \\
\hline & $\tilde{\mathrm{e}}$ & & & & & $\tilde{0}$ & Nasal \\
\hline & é & & $\partial^{\prime}$ & & & & Stressed \\
\hline \multirow[t]{6}{*}{ open } & $æ$ & & & & a & & Simple \\
\hline & æ: & & & & a: & & Long \\
\hline & & & & & ă & & Short \\
\hline & & & & & $a$ & & Pharyngeal \\
\hline & & & & & $\tilde{a}$ & & Nasal \\
\hline & & & & & á & & Stressed \\
\hline
\end{tabular}

PROCESSES

. pharyngealization

i palatalization

" labialization

nasalization

: intensive consonants

$\therefore$ dent-labialization

- strong consonants

\section{Overview of conventions}

General categories of grammar in discussions in text are marked by initial lower-case letter, e.g., alignment, case, nominative.

Categories representing grammar features of the database are referred to by initial upper-case letter, Alignment, Case, Simple past.

UPPER-CASE letters are used for defining grammar feature acronyms in the database, e.g., OBL, DAT, GEN, or classes of concepts in lexical data, e.g., ACTIVITIES.

SMALL CAPS are used in glossings in examples, e.g., PRS, DAT, and for general meanings (i.e., not meanings in individual languages), e.g., BULL, TO STRIKE, WOLF, PREDATOR. 